ORIGINAL ARTICLE

\title{
Effect of air pollution and environmental tobacco smoke on serum hyaluronate concentrations in school children
}

\author{
Y Fuji, M Shima, M Ando, M Adachi, Y Tsunetoshi
}

Occup Environ Med 2002;59:124-128

See end of article for authors' affiliations

\section{Correspondence to:}

Dr M Shima, Department of Public Health, Graduate

School of Medicine, Chiba

University, 1-8-1 Inohana,

Chuo-ku, Chiba

260-8670, Japan;

sima@med.m.chiba-u.ac.jp

Accepted 27 July 2001

\begin{abstract}
Objectives: To evaluate serum hyaluronate concentrations relative to air pollution, environmental tobacco smoke (ETS), and respiratory health in Japanese school children.

Methods: Respiratory symptoms and serum lgE concentrations were examined in 1037 school children living in four communities in Japan with differing levels of air pollution. Serum hyaluronate concentrations were assayed in 230 children, consisting of all the children who had symptoms of either asthma or wheeze (65 and 50 subjects, respectively) and normal controls adjusted for sex, school grade, and school without these symptoms (115 subjects).

Results: Although serum hyaluronate concentrations did not differ for either asthma or wheeze, the concentrations were significantly higher in children living in communities with higher levels of air pollution. Children with asthma or wheeze and those with serum lgE concentrations of $250 \mathrm{lU} / \mathrm{ml}$ or above showed differences in hyaluronate concentrations that related to the degree of air pollution in the communities. In children with higher serum IgE concentrations, the hyaluronate concentrations among subjects exposed to ETS were significantly higher than among those without exposure to ETS.

Conclusions: The present results suggest that serum hyaluronate concentration is related to the degree of air pollution and exposure to ETS. Children with asthma or wheeze and children with higher lgE concentrations are considered to be more susceptible to environmental factors.
\end{abstract}

W ith increasing motorisation in Japan, urban air pollution, due mainly to nitrogen dioxide $\left(\mathrm{NO}_{2}\right)$ and particulate matter less than $10 \mu \mathrm{m}$ in diameter $\left(\mathrm{PM}_{10}\right)$, has increased ${ }^{2}$ and has caused much concern for human health. ${ }^{3}$ Epidemiological studies so far have primarily focused on the effect of air pollution on respiratory diseases and symptoms. ${ }^{4-6}$ There has long been a need for sensitive biochemical markers to evaluate the effects of air pollution, ${ }^{378}$ but none has yet been identified for this purpose.

Hyaluronate (hyaluronic acid), a glycosaminoglycan, is a connective tissue element in lung parenchyma, involved in the growth and development of the lungs. ${ }^{9}$ Increases in hyaluronate concentrations have been noticed during injury and repair processes in lung tissue, suggesting that hyaluronate may be a biochemical marker for lung injury. ${ }^{10}{ }^{11}$ Hyaluronate is present at very low concentrations in serum; the development of an enzyme immunoassay has enabled its concentrations to be determined quantitatively. ${ }^{12}$ Serum hyaluronate concentrations have been found to increase in rheumatoid arthritis ${ }^{13}$ and chronic liver diseases. ${ }^{14}$ In a previous study, ${ }^{15}$ we reported that serum hyaluronate concentrations in children living in a district containing major roads used heavily by dumper trucks were increased, compared with those in children living further away from major roads, and that the difference in the hyaluronate concentrations between the two groups was significant in children with higher serum IgE concentrations.

In the present study, we measured both serum IgE and hyaluronate concentrations in school children living in four communities in Japan with differing degrees of air pollution. We then analyzed the relations among these concentrations and residential factors, environmental tobacco smoke (ETS), and respiratory symptoms.

\section{MATERIALS AND METHODS}

\section{Subjects}

We studied 1526 pupils (grades 3-5; 8-11 years old) from five elementary schools in Japan: one in Osaka City (Osaka), two
Table 1 Average concentrations of atmospheric air pollutants in study communities

\begin{tabular}{|c|c|c|c|c|c|c|}
\hline & \multicolumn{2}{|c|}{$\mathrm{NO}_{2}(p p m)$} & \multicolumn{2}{|c|}{$\mathrm{SO}_{2}(\mathrm{ppm})$} & \multicolumn{2}{|c|}{$\mathrm{PM}_{10}\left(\mu \mathrm{g} / \mathrm{m}^{3}\right)$} \\
\hline & 10 year* & $1994 \dagger$ & 10 year* & $1994 \dagger$ & 10 year* & $1994 \dagger$ \\
\hline & 0.034 & 0.033 & 0.008 & 0.007 & 45 & 44 \\
\hline Kimitsu & 0.018 & 0.019 & 0.006 & 0.007 & 37 & 38 \\
\hline Obitsu & 0.011 & 0.010 & 0.004 & 0.004 & 34 & 33 \\
\hline Miyazaki & 0.007 & 0.007 & 0.003 & 0.003 & $28 \ddagger$ & $28 \ddagger$ \\
\hline
\end{tabular}

*The average concentrations of air pollutants for the 10 year period 1986-95, measured at ambient air monitoring stations near the study school; tannual mean concentrations of air pollutants in 1994; the concentration of $\mathrm{PM}_{10}$ in Miyazaki was estimated from the concentrations measured in the adjacent cities.

near the sea in Kimitsu City, Chiba Prefecture (Kimitsu), one in a high region of Chiba Prefecture (Obitsu), and one in Miyazaki Prefecture (Miyazaki). The characteristics of the study population and their environments have been described in a previous report. ${ }^{16}$ The average concentrations of atmospheric air pollutants, measured at monitoring stations near the study schools, are presented in table 1. The distances between a school and a monitoring station ranged from 0 to $500 \mathrm{~m}$ except for Miyazaki, where the distance was about 15 $\mathrm{km}$, but there are few sources of air pollution in the community. In each case, no difference was found between the environment surrounding the schools and that around the monitoring stations. Osaka had the highest concentrations of all pollutants, followed by Kimitsu, which is located in an industrial region, Obitsu, which has much traffic, and Miyazaki. The concentrations of air pollutants did not change very much during the past decade in these communities.

Abbreviations: ETS, environmental tobacco smoke; $\mathrm{PM}_{10}$ particulate matter of aerodynamic diameter $<10 \mu \mathrm{m}$ 


\section{Data collection, blood sampling, and laboratory} measurements

In November 1994, a standard respiratory symptom questionnaire - that is, the modified Japanese version of ATSDLD-78- $\mathrm{C}^{17}$ - was sent to all the subjects through their schools, to be completed by parents or guardians. We requested that incomplete questionnaires be completed. Children who had two or more episodes of wheeze accompanied with dyspnoea in the past and who had asthmatic attacks or the need for any medical treatment for asthma in the previous 2 years, as reported in the questionnaires, were considered to have "asthma." Children who had two or more wheezing episodes in the previous 2 years without a history of asthma were considered to have wheeze. In cases where any family member smoked in the presence of the child, the child was considered to have exposure to ETS.

Blood samples were collected from 1037 children between November 1994 and January 1995, after questionnaires and written consent had been returned from their parents. Blood samples collected in the morning were centrifuged on the same day; after total serum IgE concentrations were measured, the serum specimens were stored at $-80^{\circ} \mathrm{C}$. Subjects whose serum hyaluronate concentrations were assayed for this study consisted of all children who had either asthma or wheeze ( 65 and 50 subjects, respectively) among the original population ( 1037 children), and 115 control children without asthma or wheeze. Those controls were matched for sex, school grade, and school, and were selected from the non-symptomatic children (922 subjects). Children who had either fever or cold symptoms on the sampling and the previous days were excluded.

The concentration of total serum IgE was measured with a radioimmunosorbent test and hyaluronate concentrations were measured with a sandwich binding protein assay kit (Chugai Pharmaceutical, Tokyo, Japan). ${ }^{12}$

\section{Data analysis}

As the serum concentrations of hyaluronate were roughly log normally distributed, logarithms of the measurements were used for analysis. The results were expressed as geometric means and $95 \%$ confidence intervals, which were compared for sex, school grade, asthma or wheeze, serum IgE concentrations, exposure to ETS, and study community.

To analyze the relation between serum IgE, a marker for atopic predisposition, and serum hyaluronate, concentrations of hyaluronate were compared between children with serum
IgE concentrations of $250 \mathrm{IU} / \mathrm{ml}$ or above and those with concentrations below $250 \mathrm{IU} / \mathrm{ml}$, as described in a previous report. ${ }^{15}$ The geometric means of hyaluronate concentrations were adjusted for sex, school grade, asthma or wheeze, serum IgE concentrations, exposure to ETS, and study community using the general linear model. Significance of the difference of hyaluronate concentrations between the study communities was evaluated by Tukey's method. Also, trends in their alterations relative to the degree of air pollution in those communities were evaluated with a linear model that included concentrations of air pollutants (scored 1-4) as an independent variable.

Then, after the children were divided into two groups (children with or without asthma or wheeze, and children with higher or lower serum IgE concentrations), the geometric means of hyaluronate concentrations, adjusted for sex and school grade in each group, were compared relative to exposure to ETS and study communities. Statistical analyses were performed with SYSTAT programs (SPSS, Chicago, IL, USA).

\section{RESULTS}

The demographic and health characteristics of the study subjects are shown in table 2. Boys showed a higher prevalence of asthma or wheezing symptoms. The rate of occurrence of higher serum IgE concentrations (250 IU/ml or more) was $83.1 \%$ in children with asthma and $66.0 \%$ in children with wheeze, whereas it was only $20.9 \%$ in children without these symptoms. There were no differences among the three groups for school grade, exposure to ETS, or study communities.

Serum hyaluronate concentrations in children for the variable factors (sex, school grade, asthma or wheeze, exposure to ETS, and study communities) are shown in table 3. Serum hyaluronate concentrations were higher in girls than in boys, and highest in Osaka, followed by Kimitsu, Obitsu, and Miyazaki, the same order as their concentrations of air pollutants. Testing for trends showed that hyaluronate concentration increased significantly with the degree of air pollution in each community. Children living in Osaka and Kimitsu showed significantly higher serum hyaluronate concentrations than those living in Miyazaki. The difference in hyaluronate concentration between children with and without exposure to ETS was not significant.

In table 4, serum hyaluronate concentrations in children are compared relative to asthma or wheeze, study community, and

\begin{tabular}{|c|c|c|c|c|}
\hline Characteristics & $\begin{array}{l}\text { Children with } \\
\text { asthma }(n=65)\end{array}$ & $\begin{array}{l}\text { Children with } \\
\text { wheeze }(n=50)\end{array}$ & $\begin{array}{l}\text { Other children } \\
\text { whose blood } \\
\text { samples were } \\
\text { available ( } n=922 \text { ) }\end{array}$ & $\mathrm{p}$ Value \\
\hline \multicolumn{5}{|l|}{ Sex: } \\
\hline Boys & 66.2 & 64.0 & 50.9 & \multirow[t]{2}{*}{0.014} \\
\hline Girls & 33.8 & 36.0 & 49.1 & \\
\hline \multicolumn{5}{|l|}{ School grade: } \\
\hline 3rd & 33.8 & 42.0 & 35.6 & \multirow[t]{3}{*}{0.367} \\
\hline 4 th & 40.0 & 30.0 & 30.0 & \\
\hline 5 th & 26.2 & 28.0 & 34.5 & \\
\hline \multicolumn{5}{|c|}{ Serum lgE concentration: } \\
\hline $0-249 \mathrm{IU} / \mathrm{ml}$ & 16.9 & 34.0 & 79.1 & \multirow[t]{2}{*}{$<0.001$} \\
\hline$\geqslant 250 \mathrm{IU} / \mathrm{ml}$ & 83.1 & 66.0 & 20.9 & \\
\hline \multicolumn{5}{|c|}{ Environmental tobacco smoke: } \\
\hline Yes & 55.4 & 62.0 & 61.9 & \multirow[t]{2}{*}{0.576} \\
\hline No & 44.6 & 38.0 & 38.1 & \\
\hline \multicolumn{5}{|l|}{ Study community: } \\
\hline Osaka & 22.7 & 16.0 & 18.9 & \multirow[t]{4}{*}{0.404} \\
\hline Kimitsu & 40.0 & 52.0 & 42.5 & \\
\hline Obitsu & 18.5 & 12.0 & 19.0 & \\
\hline Miyazaki & 13.8 & 20.0 & 19.6 & \\
\hline
\end{tabular}


Table 3 Serum hyaluronate concentrations $†$ (ng/ml) in children relative to variable factors

\begin{tabular}{|c|c|c|c|c|}
\hline Characteristics & $\mathrm{n}$ & GM & $95 \% \mathrm{Cl}$ & $\mathrm{p}$ Value \\
\hline \multicolumn{5}{|l|}{ Sex: } \\
\hline Boys & 150 & 10.9 & 10.0 to 12.0 & \multirow[t]{2}{*}{0.018} \\
\hline Girls & 80 & 13.2 & 11.6 to 14.9 & \\
\hline \multicolumn{5}{|l|}{ School grade: } \\
\hline $3 r d$ & 86 & 12.1 & 10.7 to 13.6 & \multirow[t]{3}{*}{0.608} \\
\hline 4 th & 82 & 11.8 & 10.4 to 13.3 & \\
\hline 5 th & 62 & 11.0 & 9.5 to 12.7 & \\
\hline \multicolumn{5}{|c|}{ Respiratory symptoms: } \\
\hline Asthma & 65 & 11.9 & 10.4 to 13.7 & \multirow[t]{3}{*}{0.854} \\
\hline Wheeze & 50 & 11.2 & 9.6 to 13.1 & \\
\hline No symptom & 115 & 11.6 & 10.5 to 12.9 & \\
\hline \multicolumn{5}{|c|}{ Serum IgE concentration: } \\
\hline $0-249 \mathrm{IU} / \mathrm{ml}$ & 105 & 11.8 & 10.6 to 13.1 & \multirow[t]{2}{*}{0.845} \\
\hline$\geqslant 250 \mathrm{IU} / \mathrm{ml}$ & 125 & 11.6 & 10.5 to 12.8 & \\
\hline \multicolumn{5}{|c|}{ Environmental tobacco smoke: } \\
\hline Yes & 133 & 12.1 & 11.0 to 13.4 & \multirow[t]{2}{*}{0.223} \\
\hline No & 97 & 11.1 & 9.9 to 12.4 & \\
\hline \multicolumn{5}{|l|}{ Study community: } \\
\hline Osaka & 52 & 13.6 ** & 11.7 to 15.8 & \multirow[t]{4}{*}{$0.001 \ddagger$} \\
\hline Kimitsu & 104 & $12.3^{*}$ & 11.0 to 13.6 & \\
\hline Obitsu & 36 & 10.5 & 8.7 to 12.6 & \\
\hline Miyazaki & 38 & 9.2 & 7.7 to 10.9 & \\
\hline
\end{tabular}

${ }^{*} \mathrm{p}<0.05 ;{ }^{*} \mathrm{p}<0.01$, significantly different from children living in Miyazaki; †all values are geometric means (GM) $(95 \% \mathrm{Cl}) ; \neq p$ value for trend relative to the concentration of air pollutants in those communities.

exposure to ETS, after adjustment for sex, school grade, and serum IgE concentrations, using the general linear model. In children with asthma or wheeze, the hyaluronate concentration was highest in Osaka, followed by Kimitsu, Obitsu, and
Miyazaki, the concentration in Osaka being significantly higher than in Miyazaki. Testing for trends also showed that hyaluronate concentration increased with the concentration of air pollutants in each community. The concentration was higher in children with exposure to ETS than those without, although the difference was not significant. In children without asthma or wheeze, the hyaluronate concentration was highest in Osaka; however, the differences in concentrations among children in different study communities and between children with and without exposure to ETS were not significant.

Table 5 shows serum hyaluronate concentrations in children relative to serum IgE concentrations, study community, and exposure to ETS. In children with a higher concentration of IgE, the hyaluronate concentration was highest in Osaka, followed by Kimitsu, Obitsu, and Miyazaki, the difference in concentrations between Osaka and Miyazaki being significant. Testing for trends also indicated that hyaluronate concentrations related to air pollution. The concentration of serum hyaluronate in children with exposure to ETS was significantly higher than in those without. In children with lower serum IgE concentrations, differences in serum hyaluronate concentrations were not significant between children living in different study communities or between children with and without exposure to ETS.

\section{DISCUSSION}

The main components of air pollution in urban areas in Japan are $\mathrm{NO}_{2}$ and $\mathrm{PM}_{10}$, emitted predominantly by automobiles. ${ }^{1-3}$ Previously, we reported that in a district containing main roads used heavily by dumper trucks, serum hyaluronate concentrations in school children living near major roads were higher than in children living further away from such roads,

Table 4 Serum hyaluronate concentrations $\dagger(\mathrm{ng} / \mathrm{ml})$ in children relative to asthma or wheeze, study community, and environmental tobacco smoke

\begin{tabular}{|c|c|c|c|c|c|c|c|c|}
\hline \multirow[b]{2}{*}{ Characteristics } & \multicolumn{4}{|c|}{ Asthma or wheeze } & \multicolumn{4}{|c|}{ No symptom } \\
\hline & $\mathrm{n}$ & GM & $95 \% \mathrm{Cl}$ & $\mathrm{p}$ Value & $\mathrm{n}$ & GM & $95 \% \mathrm{Cl}$ & $p$ Value \\
\hline \multicolumn{9}{|l|}{ Study community: } \\
\hline Osaka & 26 & $14.1^{*}$ & 11.2 to 17.7 & $<0.001 \ddagger$ & 26 & 13.7 & 10.6 to 17.7 & $0.116 \neq$ \\
\hline Kimitsu & 52 & 12.7 & 10.8 to 15.0 & & 52 & 12.1 & 10.1 to 14.5 & \\
\hline Obitsu & 18 & 10.9 & 8.4 to 14.3 & & 18 & 10.1 & 7.8 to 13.0 & \\
\hline Miyazaki & 19 & 7.7 & 5.9 to 10.1 & & 19 & 11.1 & 8.4 to 14.6 & \\
\hline \multicolumn{9}{|c|}{ Environmental tobacco smoke: } \\
\hline Yes & 67 & 12.0 & 10.3 to 14.1 & 0.124 & 66 & 12.0 & 10.0 to 14.3 & 0.641 \\
\hline No & 48 & 10.2 & 8.5 to 12.3 & & 49 & 11.4 & 9.4 to 13.8 & \\
\hline
\end{tabular}

${ }^{*} p<0.05, v$ children living in Miyazaki; †all values are geometric means (GM) $(95 \% \mathrm{CI})$, adjusted with the general linear model for sex, school grade, and serum IgE concentration; $¥ p$ value for trend relative to the concentrations of air pollutants in those communities.

Table 5 Serum hyaluronate concentrations $\dagger(\mathrm{ng} / \mathrm{ml})$ in children relative to serum lgE concentrations, study community, and environmental tobacco smoke

\begin{tabular}{|c|c|c|c|c|c|c|c|c|}
\hline \multirow[b]{2}{*}{ Characteristics } & \multicolumn{4}{|c|}{ Serum $\lg E \geqslant 250 \mathrm{IU} / \mathrm{ml}$} & \multicolumn{4}{|c|}{ Serum $\lg \mathrm{E}<250 \mathrm{IU} / \mathrm{ml}$} \\
\hline & $\mathrm{n}$ & GM & $95 \% \mathrm{Cl}$ & $\mathrm{p}$ Value & $\mathrm{n}$ & GM & $95 \% \mathrm{Cl}$ & $\mathrm{p}$ Value \\
\hline \multicolumn{9}{|l|}{ Study community: } \\
\hline Osaka & 22 & $16.7^{*}$ & 12.9 to 21.5 & $<0.001 \ddagger$ & 30 & 12.0 & 9.6 to 15.0 & $0.223 \ddagger$ \\
\hline Kimitsu & 46 & 13.3 & 11.1 to 15.8 & & 58 & 11.3 & 9.6 to 13.3 & \\
\hline Obitsu & 20 & 10.8 & 8.6 to 13.7 & & 16 & 9.6 & 7.2 to 12.7 & \\
\hline Miyazaki & 17 & 7.8 & 5.9 to 10.3 & & 21 & 10.3 & 8.0 to 13.3 & \\
\hline \multicolumn{9}{|c|}{ Environmental tobacco smoke: } \\
\hline Yes & 59 & 13.1 & 11.0 to 15.6 & 0.033 & 74 & 10.8 & 9.2 to 12.6 & 0.982 \\
\hline No & 46 & 10.4 & 8.7 to 12.6 & & 51 & 10.8 & 9.0 to 12.9 & \\
\hline
\end{tabular}

${ }^{*} \mathrm{p}<0.01$, $v$ children living in Miyazaki; tall values are geometric means (GM) $(95 \% \mathrm{CI})$, adjusted with the general linear model for sex, school grade, and asthma or wheeze; $\ddagger p$ value for trend relative to the concentrations of air pollutants in those communities. 
and that, in children with higher concentrations of serum IgE, hyaluronate concentrations in serum were significantly higher in children living near major roads than in children living at greater distances from roads. ${ }^{15}$

In the present study we examined the serum hyaluronate concentrations in school children living in four different communities in Japan, and found that the hyaluronate concentration was higher in children living in areas with high concentrations of air pollution. After adjusting for sex, school grade, and other variables, the serum hyaluronate concentration was also found to be highest in children who lived in Osaka, which had the highest concentrations of air pollutants. Furthermore, the difference in hyaluronate concentrations between children in Osaka and Miyazaki, which had the lowest concentrations of air pollutants, was significant. These findings suggest an effect of air pollution on serum hyaluronate concentrations in school children, consistent with a previous study that showed that serum hyaluronate concentrations were related to the distance of their homes from major roads. ${ }^{15}$

Hyaluronate is an acidic mucopolysaccharide composed of alternately polymerised $\mathrm{N}$-acetylglucosamine and D-glucuronic acid. ${ }^{9}$ Hyaluronate is found in connective tissue and basement membranes in the body, and participates in the build up of tissue structure. ${ }^{913}$ After an injury, hyaluronate production is accelerated during the tissue repair process, with a consequential increase in its release into the circulation. ${ }^{18}$ Alveolar accumulation of hyaluronate has been shown in experimental models of lung injury, produced by administration of silica ${ }^{11}$ or irradiation, ${ }^{19}$ indicating that hyaluronate induces collagen gene expression and is relevant to the formation of lung fibrosis. In farmer's lung disease, increased hyaluronate concentrations in bronchoalveolar lavage were associated with impaired pulmonary function. ${ }^{20}$ Hyaluronate has been reported to have a protective role against inflammatory reaction ${ }^{21}{ }^{22}$ and has been indicated to be relevant to activation and inflammation of connective tissue. ${ }^{23}$ These findings suggest that serum hyaluronate may serve as a biochemical marker for lung diseases. ${ }^{24}$

In the present study no difference in serum hyaluronate concentrations was found between children who had asthma or wheeze and children without these symptoms, consistent with our previous report. ${ }^{15}$ This may have been due to stabilisation of the respiratory symptoms in the children with asthma or wheeze at the time of examination. ${ }^{16}$ Differences in hyaluronate concentrations among different communities were significant in children who had asthma or wheeze, whereas it was not significant in children without these symptoms. In children with IgE concentrations of $250 \mathrm{IU} / \mathrm{ml}$ or above, there was a notable association between hyaluronate concentrations and the degree of air pollution, whereas in children with IgE concentrations below $250 \mathrm{IU} / \mathrm{ml}$, no significant association was found. These results suggest that children who had asthma or wheeze and children with higher concentrations of IgE are more susceptible to air pollution, consistent with our previous report, ${ }^{15}$ demonstrating that serum hyaluronate concentrations in children with higher IgE concentrations were related to the distance of their homes from major roads. Furthermore, in children with higher IgE concentrations, the difference in hyaluronate concentrations was significant between children with and without exposure to ETS.

The concentration of serum IgE has been used as a marker for atopic predisposition ${ }^{25}$; this concentration is known to be higher in people with bronchial hyperresponsiveness. ${ }^{26}$ Diesel exhaust particles, a principal component of air pollution, have been shown to increase production of human IgE antibodies and to be associated with allergic reactions in the body. ${ }^{27}{ }^{28} \mathrm{In}$ Japanese school children, however, no differences in serum IgE concentrations were found among communities, and no effects of air pollution on its concentrations have been detected. ${ }^{15} 29$ On the other hand, children who have atopic pre-

\section{Main messages}

- Serum hyaluronate concentrations were evaluated relative to air pollution, environmental tobacco smoke (ETS), and respiratory symptoms in Japanese school children.

- Serum hyaluronate concentrations did not differ for either asthma or wheeze.

- Serum hyaluronate concentrations were significantly higher in children living in communities with higher levels of air pollution.

- Children with asthma or wheeze and those with serum lgE concentrations of $250 \mathrm{lU} / \mathrm{ml}$ or above showed marked correlation between hyaluronate concentrations and degree of air pollution in communities.

- In children with higher serum IgE concentrations, the hyaluronate concentration among subjects exposed to ETS was significantly increased compared with those without exposure to ETS.

\section{Policy implications}

- Serum hyaluronate concentrations were related to the degree of exposure to air pollution and environmental tobacco smoke (ETS).

- Children with asthma or wheeze and children with higher lgE concentrations are considered to be more susceptible to environmental factors.

- The relations between serum hyaluronate concentrations and air pollution, exposure to ETS, and other environmental factors should be further clarified.

disposition have been suggested to be susceptible to environmental factors-such as air pollution and passive smoking. ${ }^{30-32}$ The present findings also suggest that children with asthma or wheeze and children with higher IgE concentrations were susceptible to air pollution and exposure to ETS. No significant difference in serum hyaluronate concentration, however, was found between children who had asthma or wheeze and children without these symptoms, leaving the physiological significance of hyaluronate concentrations unclear.

Shima et $a l^{16}$ measured acute phase proteins $\mathrm{C} 3 \mathrm{C}$ and $\mathrm{C} 4$ in the same subjects as in the present study, and reported that these proteins reflected the concentrations of air pollutants. A significant increase of serum $\mathrm{C} 3 \mathrm{C}$ has also been detected in residents of areas with high concentrations of air pollution ${ }^{33}$ and in boys exposed to ETS. ${ }^{34}$ These findings show that air pollution and exposure to ETS can induce an increase of host defence mechanisms. ${ }^{16}$ Acute inflammation in the body may cause increased concentrations of several proteins in serum. ${ }^{35}$ Children with signs of acute inflammation, such as cold and fever, therefore, were excluded from this study. In the present study we also measured C-reactive protein, a marker for inflammation, and found that the concentration was below the lower limit of detection in most subjects in all communities (data not shown), indicating that the difference in hyaluronate concentrations between study communities was not due to the prevalence of any inflammatory disease.

In conclusion, we have shown that serum hyaluronate concentrations in school children were significantly higher in communities with higher concentrations of air pollutants. Children who had asthma or wheeze and those with serum IgE concentrations of $250 \mathrm{IU} / \mathrm{ml}$ or above, in particular, showed greater differences in their hyaluronate concentrations among communities, suggesting their possible susceptibility to air pollution. In children with higher IgE concentrations, serum hyaluronate concentrations were significantly higher in subjects exposed to ETS than in unexposed subjects. The relations between hyaluronate concentrations and air 
pollution, exposure to ETS, and other environmental factors need to be clarified with more study subjects, and the physiological significance of the varying concentrations of serum hyaluronate should be further examined.

\section{Authors' affiliations}

Y Fuji, M Shima, M Ando, M Adachi, Department of Public Health, Graduate School of Medicine, Chiba University, Chiba, Japan Y Tsunetoshi, Department of Public Health, Miyazaki Medical College, Kiyotake-cho, Miyazaki, Japan

\section{REFERENCES}

1 Tamura K, Ando M, Sagai M, et al. Estimation of levels of personal exposure to suspended particulate matter and nitrogen dioxide in Tokyo. Environ Sci 1996:4:37-51.

2 Shima $M$, Adachi $M$. Indoor nitrogen dioxide in homes along trunk roads with heavy traffic. Occup Environ Med 1998;55:428-33

3 Nitta H, Sato T, Nakai S, et al. Respiratory health associated with exposure to automobile exhaust. I. Results of cross sectional studies in 1979,1982 and 1983. Arch Environ Health 1993:48:53-8.

4 Shima M, Adachi M. Effect of outdoor and indoor nitrogen dioxide on respiratory symptoms in school children. Int J Epidemiol 2000;29:862-70.

5 Ferris BG Jr, Speizer FE, Spengler JD, et al. Effects of sulfur oxides and respirable particles on human health: methodology and demography of populations in study. Am Rev Respir Dis 1979;1 20:767-79.

6 Ackermann-Liebrich U, Leuenberger P, Schwartz J, et al. Lung function and long term exposure to air pollutants in Switzerland. Am J Respir Crit Care Med 1997; 155:122-9.

7 Griffith J, Duncan RC, Hulka BS. Biochemical and biological markers: implications for epidemiologic studies. Arch Environ Health 1989;44:375-81.

8 Beck BD, Greaves IA. Screening and monitoring for non-neoplastic pulmonary disease. In: Brain JD, Beck BD, Warren AJ, et al, eds. Variations in susceptibility to inhaled pollutants. Baltimore: Johns Hopkins University Press, 1988:335-75.

9 Laurent TC, Fraser JRE. Hyaluronan. FASEB J 1992;6:2397-404.

10 Bjermer L, Eklund A, Blaschke E. Bronchoalveolar lavage fibronectin in patients with sarcoidosis: correlation to hyaluronan and disease activity. Eur Respir J 1991:4:965-71.

11 Eklund A, Tornling G, Blaschke E, et al. Extracellular matrix components in bronchoalveolar lavage fluid in quartz exposed rats. $\mathrm{Br} J$ Ind Med 1991;48:776-82.

12 Chichibu K, Matsuura T, Shichijo S, et al. Assay of serum hyaluronic acid in clinical application. Clin Chim Acta 1989;181:317-24.

13 Goldberg RL, Huff JP, Lenz ME, et al. Elevated plasma levels of hyaluronate in patients with osteoarthritis and rheumatoid arthritis. Arthritis Rheum 1991;34:799-807.

14 Engström-Laurent A, Lööf L, Nyberg A, et al. Increased serum levels of hyaluronate in liver disease. Hepatology 1985;5:638-42.

15 Shima M, Adachi M. Serum immunoglobulin E and hyaluronate levels in children living along major roads. Arch Environ Health 1996;51:425-30.
16 Shima M, Adachi M, Tanaka T, et al. Serum complement concentrations in school children living in areas with different levels of air pollution in Japan. Arch Environ Health 1999;54:264-70

17 Ferris BG. Epidemiology standardization project. II. Recommended respiratory disease questionnaires for use with adults and children in epidemiological research. Am Rev Respir Dis 1978;118(suppl 6):7-53.

18 Laurent TC, Dahl IMS, Dahl LB, et al. The catabolic fate of hyaluronic acid. Connect Tissue Res 1986;15:33-41.

19 Li Y, Rahmanian M, Widstrom C, et al. Irradiation-induced expression of hyaluronan (HA) synthase 2 and hyaluronidase 2 genes in rat lung tissue accompanies active turnover of $\mathrm{HA}$ and induction of type I and III collagen gene expression. Am J Respir Cell Mol Biol 2000;23:41 1-8.

20 Larsson K, Eklund A, Malmberg P, et al. Hyaluronic acid (hyaluronan) in BAL fluid distinguishes farmers with allergic alveolitis from farmers with asymtomatic alveolitis. Chest 1992;101:109-14.

21 Cantor JO, Cerreta JM, Armand G, et al. The pulmonary matrix, glycosaminoglycans and pulmonary emphysema. Connect Tissue Res 1999;40:97-104.

22 Cantor JO, Shteyngart B, Cerreta JM, et al. The effect of hyaluronan on elastic fiber injury in vitro and elastase-induced airspace enlargement in vivo. Proc Soc Exp Biol Med 2000;225:65-71.

23 Gerdin B, Hällgren R. Dynamic role of hyaluronan (HYA) in connective tissue activation and inflammation. J Int Med 1997;242:49-55.

24 Hällgren R, Eklund A, Engström-Laurent A, et al. Hyaluronate in bronchoalveolar lavage fluid: a new marker in sarcoidosis reflecting pulmonary disease. BM 1985:290:1778-81.

25 Marsh DG. Genetic and molecular analysis of human immune responsiveness to allergens. In: Marsh DG, Lockhart A, Holgate ST, eds. The genetics of asthma. Oxford: Blackwell, 1993:201-13.

26 Burrows B, Sears MR, Flannery EM, et al. Relationships of bronchial responsiveness assessed by methacholine to serum lgE, lung function, symptoms, and diagnoses in 11 -year-old New Zealand children. $J$ Allergy Clin Immunol 1992;90:376-85

27 Diaz-Sanchez D, Dotson AR, Takenaka H, et al. Diesel exhaust particles induce local lgE production in vivo and alter the pattern of $\lg E$ messenge RNA isoforms. J Clin Invest 1994;94:1417-25.

28 Takenaka H, Zhang K, Diaz-Sanchez D, et al. Enhanced human IgE production results from exposure to the aromatic hydrocarbons from diesel exhaust: direct effects on B-cell IgE production. J Allergy Clin Immunol 1995;95:103-15.

29 Tanaka T, Nakamura H, Hiratsuka T, et al. Relationship between serum lgE levels and respiratory symptoms in school children. J Health Welfare Stat 1990;37:9-14. (In Japanese.)

30 Pierson WE, Koenig JQ. Respiratory effects of air pollution on allergic disease. J Allergy Clin Immunol 1992;90:557-66.

31 Antó JM, Sunyer J. Nitrogen dioxide and allergic asthma: starting to clarify an obscure association. Lancet 1995;345:402-3.

32 Forastiere F, Agabiti N, Corbo GM, et al. Passive smoking as a determinant of bronchial responsiveness in children. Am J Respir Crit Care Med 1994;149:365-70.

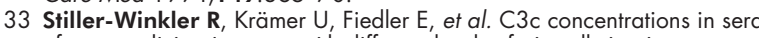
of persons living in areas with different levels of air pollution in Northrhine-Westphalia (Federal Republic of Germany). Environ Res 1989;49:7-19.

34 Shima $M$, Adachi $M$. Effects of environmental tobacco smoke on serum levels of acute phase proteins in schoolchildren. Prev Med 1996;25:617-24

35 Kushner I, Mackiewicz A. Acute phase proteins as disease markers. Dis Markers 1987;5:1-11. 